\title{
A Qualitative Study on Logistics Educational Needs in Malaysian Higher Education Institutions: A Perspective from Logistics Practitioners
}

\author{
Dazmin bin Daud (Corresponding author) \\ Faculty of Management and Information Technology, UCSI University \\ 1, Jalan Menara Gading, UCSI Heights, 56000 Kuala Lumpur, Malaysia \\ Tel: +6-012-2902513 E-mail: dazmindaud@ucsi.edu.my \\ Halim bin Ahmad \\ Faculty of Business, University Industry of Selangor \\ Shah Alam Campus, Section 7, 40000 Shah Alam, Selangor, Malaysia \\ Tel: +6-03-55223532 E-mail: ugsm@unisel.edu.my
}

Accepted: 25 July, $2011 \quad$ DOI: 10.5296/ijhrs.v1i1.867

\begin{abstract}
The purpose of this article is to provide a perspective view pertaining to logistics educational needs (LEN) in undergraduate logistics programmes from Malaysian logistics practitioners. It focuses on the perception concerning courses required in logistics programmes offered by the Malaysian higher education institutions from 43 respondents. The objective of this study is to discover what is important across the constructs of courses in logistics program using an open-ended questionnaire. It deals with the exploratory approach to LEN and its relevancy in the present logistics curriculum. The findings show that 39 items were derived from the study and were grouped under knowledge, skills and working experience. The findings are considered to create a roadmap to design a quantitative study for exploring LEN in the Malaysian undergraduate logistics programmes.
\end{abstract}

Key words: logistics educational needs, courses, skills, working experience

\section{Introduction}

Thought on logistics education needs (LEN) has evolved from transportation to logistics and supply chain management. Logistics have developed starting from the military logistics to physical distribution management (Gubbins, 1988) and then to integrated logistics (La Londe, 
1994) and supply chain management (Lambert, Cooper \& Pagh, 1998). Therefore, the impact of the above development requires logistics to have its own profession to be taught formally in education (Masters \& Pohlen, 1994).

The problem raises of what future logisticians need to learn and what education logistics programs offer have been of growing concern, not only for higher education institutional administrators, but also for scholars and logistics practitioners. Views from Trunick (2006) indicated that higher education institutions need to provide competence and marketable logistics programs. This is to ensure that graduates will be able to use their knowledge and skills in the logistics industry. In order to explore the LEN for Malaysian logisticians, this study explores thoughts from local logistician practitioners. Views from logistics practitioners can provide LEN in terms of logistician knowledge, logistician non logistics knowledge or non logistics functional issues, logistician competency, and courses in logistics program that are being offered by higher education institutions. In order to understand the current and future needs of the logistics industry in Malaysia, it is critical for the Malaysian Ministry of Higher Education, to work in alliance with active logistics service providers in the industry. These logistics practitioners will provide latest input regarding logistics knowledge and skills required by the higher education institutions which will then use these inputs in designing their programs and curriculum by reconciling the current and future trends as well as demands of the logistics activities. The importance of developing an effective logistics curriculum can be traced back from the views of Berkovski and Gottschalk (1997), van Hoek (2000), and Closs (2000). They emphasize the needs for current higher education institutions to revise their curriculum so that they can produce competent logistics graduates.

Educators and higher education institutions need to have collaboration with logistics practitioners in order to design effective logistics programmes. Effective and competent curriculum in logistics can be achieve if these two parties working together to select courses or subjects that will contribute to competent logisticians in the $21^{\text {st }}$ century (examples see Heilmann, 2007; Crook et al., 2008).

\section{Purpose of the Study}

The purpose of this study is to provide perspectives from local logistics practitioners pertaining to LEN. This study tries to discover what is important across the constructs of courses in logistics program, knowledge of logistics functions, knowledge of non logistics functions, and logistician skills. It deals with the exploratory approach to LEN and its relevancy in the present logistics curriculum.

\section{Literature Review}


In relation to logistics, there are literatures emphasizing on the lacking of relevancy between actual working practice, application, and curriculum in academic logistics programmes (Bennis and O'Toole, 2005; Richardson, 2002; Pteffer and Fong, 2002; Closs, 2000). Logistics programmes offered by higher education institutions must adapt with the development of logistics (Kent \& Flint, 1997).

There are literatures which focus on the trend of shifting traditional logistics curriculum structures into cross-functional discipline. For example, van Hoek (2000) indicated that logistics practitioners prefer applied logistics programmes rather than totally theoretical approach in the university logistics programs. In another example, Lancioni, Forman and Smith (2000) have studied a comparative logistics programs in universities between the cross-functional discipline and the traditional curriculum structures. Their research showed that there is a trend of shifting from the traditional curriculum structures into the cross-functional discipline. Meanwhile, a study from Wu (2007) has resulted that logistics programmes at higher education institutions offer more non-logistics courses compare to courses which directly relate to logistics. In a related issue, there is a need for practitioners to become an academician so that the actual and recent knowledge and skills can be transferred to the students at higher education institution (Clinebell and Clinebell, 2008).

In conjunction with LEN, Lancioni, Forman and Smith (2001) argued that logistics programs which fail in designing the curriculum tend to reflect the international setting and the multi-disciplinary nature in logistics and supply chain management. Internationally, the distribution of logistics programs, types of programs, types of courses (logistics functions and non logistics functions) varied between one nation compared to another (Wu, 2007). Wu also indicated that there was a strong relationship between higher education institutions offering degrees in logistics programs and higher rate of employability. There are logistics scholars who are aware of the importance of logistics education and curriculum as a research topic and its implications to logistics students, scholars and practitioners; higher education institutions; and employability (Grant, 2001).

\section{Methodology}

An exploratory study was conducted using 46 Malaysian logistics managers as respondents in order to seek their ideas about LEN. The ideas from the respondents may provide salient inputs of LEN which are important towards the Malaysian scenario. Their views were sought to describe suitable courses in undergraduate logistics programmes. An exploratory study would provide an advantage by seeking information from persons experienced in the area of study, by tapping into their collective memories and experiences (Cooper \& Schindler, 2008).

A judgment sampling was used to conduct the exploratory study. The judgment sampling is a purposive sampling where the researcher selects subject samples to conform to some criterion and is based on the basis of subject expertise in the subject investigation (Sekaran \& Bougie, 
2010). In judgment sampling, the sample elements are selected because they are believed to be representatives of the population of interest and are expected to serve the research purpose of a study (Cooper \& Schindler, 2008).

This study executes judgment sampling based on the guidelines from Churchill (1979) and Deming (1975). An open-ended questionnaire survey was used in the exploratory study. An open-ended questionnaire is a measurement question where the respondent chooses the words to frame the answer (Cooper \& Schindler, 2008). The design of open-ended questions in the exploratory study was based on the guidelines from Reja, Manfreda, Hlebec, and Vehovar (2003) and Krause (2002).

The open-ended questions for capturing dimensions of LEN were constructed using a modification of instrument from Murphy and Poist (2007). 3 demographical questions and 4 open-ended questions (see Table 3.1) were designed for the questionnaire (see Table 1).

Table 1: Demographical and Open-ended Questions for Respondents on Exploring the Logistics Educational Needs

\section{Section A: Demographical Information}

Q1. Position

Q2. Working experience

Q3. Type of company (local or multinational)

Section B: Logistics educational needs constructs

Q1 Can you describe knowledge of logistics functions that you perceive as important for logistics graduates to make them competent in the $21^{\text {st }}$ century?

Q2 What are the non logistics knowledge that you perceive as important for logistics graduates to make them competent in the $21^{\text {st }}$ century?

Q3 What are the skills and competencies that you perceive as important for logistics graduate to make them competent in the $21^{\text {st }}$ century?

Q4 What are the important subjects offered by undergraduate logistics programs in the Malaysian higher education institutions that you perceive as important for logistics graduates to make them competent in the $21^{\text {st }}$ century?

A potential list of 50 respondents who are currently working in the Klang Valley was generated from the Malaysia's Chartered Institute of Logistics and Transport directory. Although 50 undoubtedly would have contributed extremely valuable information and perspectives, resource constraints limited the survey to 43 (response rate 86\%). 7 respondents were unable to participate. An appointment has been set up to meet the respondents respectively. This method is called "drop-off" where a researcher makes an appointment to see the respondent (see Brehm, Eisenhauer \& Krannich, 2006; Steele et al., 2001). The researcher further explained the 
questionnaire briefly and then left it with the respondents to complete it based on a dateline upon which the researcher will return to collect the completed survey. A survey that consists of a cover letter and a copy of the questionnaire was given personally by a researcher to 43 Malaysian logisticians who are working within the Klang Valley. These logisticians held middle and top management posts in logistics firms. Table 2 shows the demographical information about the respondents.

Respondents were asked to contribute salient outputs related to LEN in Malaysia. Completed surveys were taken back personally from the logisticians. This activity took place between September 3, 2010 and November 19, 2010. The surveys were then analyzed independently by each researcher for common themes. The list from each respondent was compared and the duplicate and irrelevant items removed. Themes were then coded, grouped, and reconciled, and the findings were compared with the dimensions of LEN. These qualitative procedures were based on the guidance from Anfara, Brown and Mangione (2002) and Patton (1999).

\section{Findings and Discussion}

The objective of this research is to explore views on LEN based on a perspective of Malaysian logistics practitioners. Their views were categorized qualitatively into course, skills and working experience. The results of this qualitative study may provide valuable inputs in developing a survey instrument for a quantitative study. Feedbacks from respondents as key informants in logistics indicated that areas in course, skills and working experience represent courses in logistics program, knowledge of logistics functions, knowledge of non logistics functions, and logistician skills.

The responding logisticians in the study were all male. The majority of them occupied middle positions $(60.5 \%)$ in their respective organizations with an average of 9.6 years working experience. $28(65.1 \%)$ of them worked in local logistics firms and the balance worked in multinational logistics firms. The lists of LEN from each respondent were compared in duplicate and irrelevant items were removed. Table 3.0 shows a final listing of key areas which come from the judgment sampling.

Table 2: Demographical Information for Respondent $(n=43)$

\begin{tabular}{lccc}
\hline Usable Surveys & & 43 \\
Response Rate & & \multicolumn{1}{c}{$86 \%$} \\
Average Number of Years of Experience & \multicolumn{1}{c}{ Category } & Frequency & Percentage $(\%)$ \\
\hline Demographic Variable & \multicolumn{1}{c}{ Top Management } & 17 & 39.5 \\
\hline Position & Middle Management & 26 & 60.5 \\
& Multinational & 15 & 34.9 \\
Company Category & Local & 28 & 65.1 \\
\hline
\end{tabular}


Referring to Table 3.0, respondents had emphasized on 32 salient courses for undergraduate logistics programmes. These 31 items were grouped in a category called "Course". All items in "Cource" were perceived by respondents towards having knowledge and skills which are important for logisticians. Courses which were considered as a core in logistics contributed 12 items $(38.7 \%)$ from the list. The remaining of 19 items $(61.3 \%)$ made up of non-core for logistics courses. Logistics study, supply chain management, marketing, customer relationship management, English language, safety and security, and international business courses were found and identified in all the respondents' feedback. Courses such as geography and mathematics were uniquely obtained from this study.

Table 3: The 43 Respondents Perspective on Malaysian Higher Education Institutional Logistics Educational Needs

\begin{tabular}{|c|c|c|}
\hline Group 1 & Group 2 & Group 3 \\
\hline Air transport $[\mathrm{L}]$ & Analytical thinking & Working experience \\
\hline Business study [NL] & Creativity & \\
\hline Communication [NL] & Open minds & \\
\hline Computer study [NL] & Positive behaviour & \\
\hline Containerization [L] & Positive mind set & \\
\hline Customer relationship management & Understanding standard operating & \\
\hline$[\mathrm{NL}]$ & procedure (SOP) & \\
\hline \multicolumn{3}{|l|}{ Economics [NL] } \\
\hline \multicolumn{3}{|l|}{ English language [NL] } \\
\hline \multicolumn{3}{|l|}{ Entrepreneurship [NL] } \\
\hline \multicolumn{3}{|l|}{ Finance $\&$ accounting [NL] } \\
\hline \multicolumn{3}{|l|}{ General management [NL] } \\
\hline \multicolumn{3}{|l|}{ Geography [NL] } \\
\hline \multicolumn{3}{|l|}{ Human resource management [NL] } \\
\hline \multicolumn{3}{|l|}{ International business [NL] } \\
\hline \multicolumn{3}{|l|}{ Inventory [L] } \\
\hline \multicolumn{3}{|l|}{ Industrial relations [NL] } \\
\hline \multicolumn{3}{|l|}{ Law of carriage $[\mathrm{L}]$} \\
\hline \multicolumn{3}{|l|}{ Logistics study [L] } \\
\hline \multicolumn{3}{|l|}{ Logistics strategy [L] } \\
\hline \multicolumn{3}{|l|}{ Maritime transport [L] } \\
\hline \multicolumn{3}{|l|}{ Marketing [NL] } \\
\hline \multicolumn{3}{|l|}{ Mathematics [NL] } \\
\hline \multicolumn{3}{|l|}{ Organizational behavior [NL] } \\
\hline \multicolumn{3}{|l|}{ Organizational development \& } \\
\hline \multicolumn{3}{|l|}{ change $[\mathrm{NL}]$} \\
\hline Port management $[\mathrm{L}]$ & & \\
\hline
\end{tabular}


Procurement [L]

Safety \& security [NL]

Supply chain management [L]

Warehousing [L]

Transportation \& terminal [L]

Quantitative methods \& problem

solving [NL]

Note: $\mathrm{L}=$ Logistics Course; $\mathrm{NL}=$ Non-Logistics Course

5 items (analytical thinking, creativity, open mindedness, positive behavior, and positive mind set) were grouped in a category called "Skills" which respondents perceived as necessary for logistics students to acquire from logistics programmes. In relation to conceptual skill, respondents had highlighted analytical thinking as a necessary skill (as supported by Larson, 2008) to be obtained. Having the skills to understand standard operating procedure (SOP) (see item number 6 in the "Skills" category) was perceived as important for logistics students (for example see Hyland, Soosay \& Sloan, 2003). Respondents perceived that a familiarization with the SOP could be attained by attending industrial training or cooperative placement course. In addition, by attending industrial training, students become more competent logisticians in the future (for examples see Meredith \& Burkle, 2008; Cooper \& Faris, 2003).

An item identified as working experience did not match with "Course" and "Skills" categories. Therefore, it was decided to put it in a separate group called "Working Experience". Literature has indicated that students can acquire working experience through industrial training (Wasonga \& Murphy, 2006). In logistics education, there is an increasing acceptance of the relevance and importance of logistics internship program for firms that employ logistics interns, the students who take the internship, and the higher education institutions that offer the program (Knemeyer \& Murphy, 2001; Cooper \& Farris, 2003).

\section{Conclusion, Implications and Limitations}

This qualitative study indicated the possible relevance of the knowledge, skills and experience required in LEN for undergraduate logistics programmes. The findings of this study seem to explore dimensions of Malaysian LEN. Respondents have perceived that there must be courses which have a combination of logistics knowledge and non-logistics knowledge in the logistics programmes offered by higher education institutions. These courses theoretically should be able to demonstrate learning outcomes in the form of logistics and non-logistics knowledge; skills in analytical thinking, creativity, open minds, positive behavior, positive mind set and understanding work procedures. Students may apply these knowledge and skills when they undergo industrial training. The qualitative analysis of the knowledge, skills and experience revealed by the survey results has shown priorities in logistics study, supply chain management, marketing, customer relationship management, English language, safety and security, and international business as courses needed in logistics undergraduate programmes 
in Malaysia. This was a concern when all respondents revealed all the above courses in the survey.

The survey also indicates that about $19(61.3 \%)$ of the courses in the "Course" column comprised non-core logistics courses. The roles of logisticians have diversified into the non logistics functions since the United States's professional body; the Council of Logistics Management (CLM) became the Council of Supply Chain Management Professionals (CSCMP) (http://cscmp.org) effective January 1, 2005. Logisticians in the $21^{\text {st }}$ century are expected to have broader knowledge, not only in logistics but also procurement, manufacturing, operation and marketing (Larson, Poist \& Halldórsson, 2007). In addition, Stock (1997) used the term 'non logistics' in his study to show the relationship between logistics, accounting, psychology, economics, political science, sociology, mathematics, computing, philosophy, marketing, management, and business functions. In the future, quantitative comparative studies can be conducted to look into the significance difference between core and non-core logistics courses in the "Course" column. This would further enhance the reliability of the current findings.

Finally, this study has certain limitations that should be acknowledged. First, the sample was taken from an association's contact list. There is no doubt that there are many Malaysian logistics practitioners than those in the list. Future research direction would be to replicate this study among Malaysian logisticians in the more large respondents before any generalization could be drawn.

Second, since this study applied qualitative method and used non-probability sampling, future research in this area should attempt to explore the attributes of course, skills and working experience within the application of quantitative analysis and probability sampling (for example see Murphy and Poist, 2007).

Third, a common practice in management research is to gather perceptive rather than actual performance data (Cooper \& Schindler, 2008) and the appropriateness is frequently challenged (for example see Kreiman et al., 1993). One way to overcome this limitation is to collect available numbers of logistics graduates from public and private higher education institutions in Malaysia and numbers of logistics graduates who are employed by logistics provider firms. Financial information such as basic salary and other financial remunerations from logistics graduates who have been employed by their employers can be used as a ratio data for accurate research findings (for example see Berman, 2007).

Notwithstanding, this qualitative study has set a foundation for further quantitative research on LEN. Expanding the research to capture views from other LEN's stakeholders such as academicians teaching logistics programs, logistics students, logistics professional bodies, and Government agencies that are involved in logistics industry would provide more information of LEN in Malaysia. The information may determine different factors that influence LEN in Malaysia. Thus at the end of the day various factors from different perspectives will be blended 


\section{Macrothink}

International Journal of Human Resource Studies

ISSN 2162-3058 2011, Vol. 1, No. 1

in order to produce a competitive LEN in the logistics curriculum for the $21^{\text {st }}$ century logisticians.

\section{References}

Anfara, V.A. Jr., Brown, K.M. \& Mangione, T.L. (2002). Qualitative analysis on stage: Making the research process more public. Educational Researcher, 31(7), 28 - 38.

Bennis, W.G. \& O'Toole, J. (2005). How business schools lost their way. Harvard Business Review, 83 (5), 96 - 104.

Berkovski, B. \& Gottschalk, C.M. (1997). Strengthening human resources for new and renewable energy technologies of the 21st century. Renewable Energy, 10 (2/3), $441-450$.

Berman, J. (2007). Logistics management's $23^{\text {rd }}$ annual salary survey. Logistics Management, Issue 1 March 2007. Retrieved July 20, 2008 from http://www.logisticsmgmt.com/article/CA6424064.html.

Brehm, J.M., Eisenhauer, B.W. \& Krannich, R.S. (2006). Community attachments as predictors of local environmental concern. The case fro multiple dimensions of attachment. American Behavioral Specialist, 50(2), 142 - 165.

Churchill, G.A. Jr. (1979). A paradigm for developing better measures of marketing constructs. Journal of Marketing Research, 16(1), 64-73.

Clinebell, S.K. \& Clinebell, J.M. (2008). The tension in business education between academic rigor and real-world relevance: The role of executive professors. Academy of Management Learning \& Education, 7 (1), 99 - 107.

Closs, D.J. (2000). Preface. Journal of Business Logistics, 21 (1), i - iii.

Cooper, D.R. and Schindler, P.S. (2008). Business research methods (10th ed.). New York: McGraw-Hill Irwin.

Cooper, M.C. \& Farris, M.T. (2003). How can we add value to logistics education? Logistics Spectrum, 37(3), $4-8$.

Crook, T.R., Giunipero, L., Reus, T.H., Handfield, R., \& Wiliams, S.K. (2008). Antecedents and outcomes of supply chain effectiveness: An exploratory investigation. Journal of Managerial Issues, 20(2), 161 - 177. 


\section{Macrothink}

International Journal of Human Resource Studies

ISSN 2162-3058

2011, Vol. 1, No. 1

Deming, W.E. (1975). On probability as a basis for action. The American Statistician, 29(4), 146-152.

Grant, D.B. (2001). Using block courses for teaching logistics. International Journal of Physical Distribution \& Logistics Management, 31(7/8), 574 - 84.

Gubbins, E.J. (1988). Managing Transport Operation. London: Kogan Page.

Heilmann, P. (2007). High level competence: A tool for coping with organizational change. Journal of European Industrial Training, 31(9), 727 - 741.

Hyland, P.W., Soosay, C. \& Sloan, T.R. (2003). Continuous improvement and learning in the supply chain. International Journal of Physical Distribution \& Logistics Management, $33(4), 316-335$.

Kent, J.L. Jr. \& Flint, D.J. (1997). Perspective on the evolution of logistics thought. Journal of Business Logistics, 18 (2), 15 - 29.

Knemeyer, A.M. \& Murphy, P.R. (2001). Logistics internships: Employer perspectives. Transportation Journal, 41(1), 16 - 26.

Krause, N. (2002). A comprehensive strategy for developing closed-ended survey items for use in studies of older adults. Journal of Gerontology: SOCIAL SCIENCE, 57B(5), S263 S274.

Kreiman, J., Gerratt, B.R., Kempster, G.B., Erman, A. \& Berke, G.S. (1993). Perceptual evaluation of voice quality: review, tutorial, and a framework for future research. Journal of Speech and Hearing Research, 36(1), 21 - 40.

La Londe, B.J. (1994). Evolution of the integrated logistics concept. In J.F. Robeson, W.C. Copacino \& R.E. Howe (eds.), The Logistics Handbook. New York: The Free Press, pp 3-12.

Lambert, D.M., Cooper, M.C., \& Pagh, J.D. (1998). Supply Chain Management: Implementation Issues and Research Opportunities. The International Journal of Logistics Management, 9(2), 1 - 20.

Lancioni, R., Forman, H., \& Smith, M. (2000). Logistics programs in universities: Stovepipe vs cross disciplinary. International Journal of Physical Distribution \& Logistics Management, 31 (1), 53 - 64.

Lancioni, R., Forman, H., \& Smith, M.F. (2001). Logistics and supply chain education: Roadblocks and challenges. International Journal of Physical Distribution \& Logistics 


\section{Macrothink \\ International Journal of Human Resource Studies \\ ISSN 2162-3058 2011, Vol. 1, No. 1}

Management, 31(10), $733-745$.

Larson, P.D. (2008). Accreditation program design: a survey of supply chain professionals. Journal of Enterprise Information Management, 21(4), 377 - 392.

Larson, P.D., Poist, R.F., \& Halldórson, A. (2007). Perspectives on logistics vs. SCM: A survey of SCM professionals. Journal of Business Logistics, 28(1), 1 - 24.

Masters, J.M. \& Pohlen, T.L. (1994). Evolution of the logistics profession. In J.F. Robeson, W.C. Copacino \& R.E. Howe (eds.), The Logistics Handbook. New York: The Free Press, pp 13-34.

Meredith, S. \& Burkle, M. (2008). Building bridges between university and industry: theory and practice. Education + Training, 50(3), $199-215$.

Murphy, P., \& Poist, R.F. (2007). Skill requirements of senior-level logisticians: A longitudinal assessment. Supply Chain Management: An International Journal, 12(6), 423 -431 .

Patton, M.Q. (1999). Enhancing the quality and credibility of qualitative analysis. Health Services Research, 34(5 Pt 2), 1189 - 1208.

Pteffer, J. \& Fong, C.T. (2002). The end of business schools? Less success than meets the eye. Academy of Management Learning \& Education, 1 (1). 78 - 95.

Reja, U., Manfreda, K.L., Hlebec, V. \& Vehovar, V. (2003). Open-ended vs. close-ended questions in web questionnaires. Development in Applied Statistics, 19, 159 - 177. Retrieved March 25, 2009 from http://mrvar.fdv.uni-lj.si/pub/mz/mz19/reja.pdf.

Richardson, H.L. (2002). Get closer to logistics education. Transportation \& Distribution, 43 (10), $58-64$.

Sekaran, U. \& Bougie, R. (2010). Research methods for business: A skill building approach (5th ed.). New York: John Wiley \& Sons.

Steele, J., Bourke, L., Luloff, A.E., Liao, P., Theodori, G.L. \& Krannich, R.S. (2001). The drop-off/pick-up method for household survey research. Community Development, 32(2), $238-250$.

Stock, J.R. (1997). Applying theories from other disciplines to logistics. International Journal of Physical Distribution \& Logistics Management, 27(9/10), 515 - 539. 


\section{Macrothink}

International Journal of Human Resource Studies

ISSN 2162-3058

2011, Vol. 1, No. 1

Trunick, P. A. (2006). What are you really getting from a supply chain degree? Logistics Today, Issue June 2006. Retrieved September 17, 2008 from http://outsourced-logistics.com/global_markets/outlog_story_7955/.

van Hoek, R.I. (2000). Logistics education: Achieving market and research driven skill development. International Journal of Physical Distribution \& Logistics Management, 31 (7/8), $505-519$.

Wasonga, T.A. \& Murphy, J.F. (2006). Learning from tacit knowledge: the impact of the internship. International Journal of Educational Management, 20(2), 153 - 163.

Wu, Y.J. (2007). Contemporary logistics education: An international perspective. International Journal of Physical Distribution \& Logistics Management, 37 (7), 504 - 528. 